\title{
PERBANDINGAN KONSENTRASI LARUTAN GARAM DAN AIR KELAPA TERHADAP NILAI KONDUKTIVITAS LISTRIK
}

\author{
Nyai Suminten, Sugianto Arjo, Liszulfah Roza, Aisyah Fitriana \\ Program Studi Pendidikan Fisika, Universitas Muhammadiyah Prof. Dr. Hamka \\ Email: suminten@uhamka.ac.id
}

Diterima: 29 Juli 2021. Direvisi: 24 Agustus 2021 Disetujui: 30 September 2021.

\begin{abstract}
Abstrak
Penelitian ini bertujuan untuk menganalisis perbandingan konsentrasi larutan garam dan air kelapa terhadap nilai konduktivitas listrik. Pemilihan kedua jenis zat cair ini berdasarkan pada jenis zat cair yang dapat menghantarkan arus listrik dan dapat dijadikan sebagai energi alternatif media sumber energi listrik. Metode penelitian ini menggunakan metode eksperimen. Pengambilan data eksperimen berasal dari variasi konsentrasi jenis larutan elektrolit yaitu air kelapa muda, air kelapa tua, larutan garam serta konsentrasi air sumur, dengan perbedaan volume zat cair. Daya yang digunakan sama yaitu sebesar 3 Volt, dan jarak antar dua elektroda dibuat tetap. Hasil menunjukkan bahwa rerata larutan yang memiliki kemampuan elektrolit terbesar adalah larutan air garam, air kelapa tua memiliki nilai konduktivitas yang lebih besar dibandingkan dengan nilai konduktivitas air kelapa muda. Sehingga, perbandingan nilai konduktivitas listrik diurutkan dari yang terbesar yaitu larutan garam, air kelapa tua dan selanjutnya air kelapa muda. Maka larutan garam memiliki kemampuan menghantarkan arus listrik yang lebih baik dibandingkan dengan air kelapa.
\end{abstract}

Kata Kunci: Konduktivitas Listrik, Larutan Garam, Air Kelapa.

\begin{abstract}
Research on the Comparison of the Concentration of Salt Solvent and Coconut Water on the Value of Electrical Conductivity aims to analyze the comparison of the concentration of salt Solvent and coconut water on the value of electrical conductivity. The selection of these two types of liquid is based on the type of liquid that can conduct electric current and can be used as an alternative energy source of electrical energy. This research method uses the experiments method. The results of the research data were obtained from taking data on variations in the concentration of electrolyte solvent, namely young coconut water, old coconut water, salt solvent and well water concentrations with differences in the number of ratios of liquid volume but using the same power of 3 Volts then the distance between two electrodes are made fixed. The results show that the average solution that has the largest electrolyte capability is a salt water solution, old coconut water has a conductivity value that is greater than the conductivity value of young coconut water. Thus, the comparison of electrical conductivity values is sorted from the largest, namely salt solvent, old coconut water and then young coconut water. So the salt solvent has the ability to conduct electricity better than coconut water.
\end{abstract}

Keywords: Electrical Conductivity, Salt Solvent, Coconut Water. 
Rumiati., Handayani.,\& Mahardika. - Perbandingan Konsentrasi Larutan ...

\section{PENDAHULUAN}

Listrik sangat dibutuhkan dalam kehidupan manusia, manfaatnya sangat luas diantaranya sebagai sumber penerangan, sumber energi, penghasil panas, penghasil gerak dan lain-lain. Energi listrik terjadi karena adanya aliran muatan listrik, Pada dasarnya suatu larutan asam dapat menghantarkan elektron dan hubungan kuat arus listrik menghasilkan arus listrik (Kholida, 2015). Sejalan dengan hal ini, aliran muatan listrik didapatkan salah satunya dari larutan elektrolit. Salah satu larutan elektrolit yaitu larutan garam $(\mathrm{NaCl})$ sebagaimana pendapat dari Bengi yang menyatakan bahwa "Larutan elektrolit kuat adalah larutan yang dapat menghantarkan listrik dengan baik terdapat pada larutan $\mathrm{NaCl}$ dan larutan $\mathrm{HCl}$ " (Bengi et al., 2018). Dari pernyataan tersebut jelas bahwa garam dapur $(\mathrm{NaCl})$ merupakan elektrolit kuat yang dapat menghasilkan arus listrik.

Menurut Putri "tinjauan secara kimia ketika garam terlarut dalam air, bahan ini akan terurai menjadi partikel-partikel Natrium dan Klor yang bermuatan listrik $(\mathrm{NaCl}$ merupakan elektrolit kuat yang nantinyaterurai sempurna), partikelpartikel bermuatan ini akan mengerjakan dua hal yaitu yang pertama mereka mengerubungi molekul- molekul air, sehingga mengurangi kemampuan mereka untuk membebaskan diri lepas ke udara berubah menjadi uap, yang kedua partikel-partikel Natrium dan Klorida yang bermuatan, mereka membentuk kelompok-kelompok terpisah bersama molekul-molekul air, sehingga partikel- partikel bermuatan ini akan menarik molekulmolekul air karena molekul- molekul air sendiri bermuatan (kutub positif disatu ujung dan kutub negatif diujung lain, dengan kata lain molekul air bersifat polar)" (Putri et $a l .$, 2015). Hal ini juga terintegrasi dengan konduktivitas listrik sebuah bahan atau larutan, sebagaimana penelitian yang dilakukan Sukisna yang menyebutkan bahwa "Penentuan konduktivitas listrik larutan elektrolit, yaitu kemampuan suatu larutan untuk menghantarkan arus listrik" (Sukisna, 2019). 
Rumiati., Handayani.,\& Mahardika. - Perbandingan Konsentrasi Larutan ...

\begin{abstract}
Berdasarkan ketersediaan bahan atau larutan, larutan garam $(\mathrm{NaCl})$ sangat mudah didapatkan dalam kehidupan sehari-hari begitu juga dengan air kelapa mudah untuk didapatkannya. Air kelapa mengandung banyak ion elektrolit, sehingga dijadikan salah satu sampel dari penelitian parameter konduktivitas listrik. Dengan pengujian sampel ini, maka akan didapatkan perbandingan konsentrasi larutan garam dan air kelapa terhadap nilai konduktivitas listrik.
\end{abstract}

\section{METODE}

Metode penelitian ini menggunakan metode eksperimen Alat dan bahan yang digunakan adalah sebagai berikut: bejana, batu baterai, lempeng seng, lempeng besi voltmeter, ampermeter, garam, air kelapa muda dan air kelapa tua serta air sumur. Adapun cara kerjanya adalah sebagai berikut:

1. Membuat alat percobaan sederhana.

2. Mencelupkan lempengan besi dan lempengan seng pada larutan garam maupun air kelapa baik kelapa muda maupun kelapa tua.

3. Mengamati nilai arus listrik.

4. Melakukan pengambilan data dilakukan secara berulang dengan perbandingan 1:1 pada larutan garam maupun air kelapa baik kelapa muda maupun kelapa tua.

5. Melakukan pengolahan dan analisi data

6. Membuat kesimpulan.

\section{HASIL DAN PEMBAHASAN}

Sebagaimana pada penelitian ini telah dilakukan analisis konduktivitas dari larutan elektrolit jenis air kelapa muda dan kelapa tua serta larutan garam. Sebelum mengetahui konduktivitas listrik masing-masing larutan, nilai hambatan masingmasing larutan diperoleh melalui pengukuran kuat arus dengan menggunakan daya yang sama dan perbedaan perbandingan volume larutan garam dan air kelapa yang konstan. Pengambilan sampel dilakukan secara berulang sebanyak 5 (lima) kali seperti ditunjukkan pada Tabel 1, Tabel 2, dan Tabel 3. 
Rumiati., Handayani.,\& Mahardika. - Perbandingan Konsentrasi Larutan ...

Tabel 1. Data Pengambilan sampelAir Kelapa Muda

\begin{tabular}{ccc}
\hline Percobaan & $\begin{array}{c}\text { Arus } \\
\text { (A) }\end{array}$ & $\begin{array}{c}\text { Hambatan } \\
(\text { ohm })\end{array}$ \\
\hline 1 & 0,040 & 75,000 \\
2 & 0,040 & 75,000 \\
3 & 0,040 & 75,000 \\
4 & 0,040 & 75,000 \\
5 & 0,040 & 75,000 \\
\hline Rerata & 0,040 & 75,000 \\
\hline
\end{tabular}

Tabel 2. Data Pengambilan Sampel Air Kelapa Tua

\begin{tabular}{ccc}
\hline Percobaan & $\begin{array}{c}\text { Arus } \\
\text { (A) }\end{array}$ & $\begin{array}{c}\text { Hambatan } \\
\text { (ohm) }\end{array}$ \\
\hline 1 & 0,043 & 69,767 \\
2 & 0,043 & 69,767 \\
3 & 0,043 & 69,767 \\
4 & 0,043 & 69,767 \\
5 & 0,043 & 69,767 \\
\hline Rerata & 0,043 & 69,767 \\
\hline
\end{tabular}

Tabel 3. Data Pengambilan Sampel Larutan Garam

\begin{tabular}{ccc}
\hline Percobaan & $\begin{array}{c}\text { Arus } \\
\text { (A) }\end{array}$ & $\begin{array}{c}\text { Hambatan } \\
(\mathrm{ohm})\end{array}$ \\
\hline 1 & 0,047 & 63,830 \\
2 & 0,047 & 63,830 \\
3 & 0,047 & 63,830 \\
4 & 0,047 & 63,830 \\
5 & 0,047 & 63,830 \\
\hline Rerata & 0,047 & 63,830
\end{tabular}

Berdasarkan data Tabel 1, Tabel 2 Hal ini menunjukkan bahwa dan Tabel 3, ditunjukkan bahwa konduktivitas yang paling besar rerata hambatan yang paling besar adalah larutan garam dibandingkan adalah air kelapa muda, dan rerata konduktivitas listrik pada air kelapa. arus yang besar adalah larutan garam. Jika diurutkan berbagai jenis larutan 
Rumiati., Handayani.,\& Mahardika. - Perbandingan Konsentrasi Larutan ...

elektrolit ini berdasarkan kuat arus konduktivitas listrik dari jenis larutan yang paling tinggi yaitu pertama elektrolit tersebut, sebagaimana larutan garam, selanjutnya air kelapa ditunjukkan dari Gambar 1 dan tua dan terakhir air kelapa muda. Gambar 2 .

Urutan ini juga berlaku terhadap

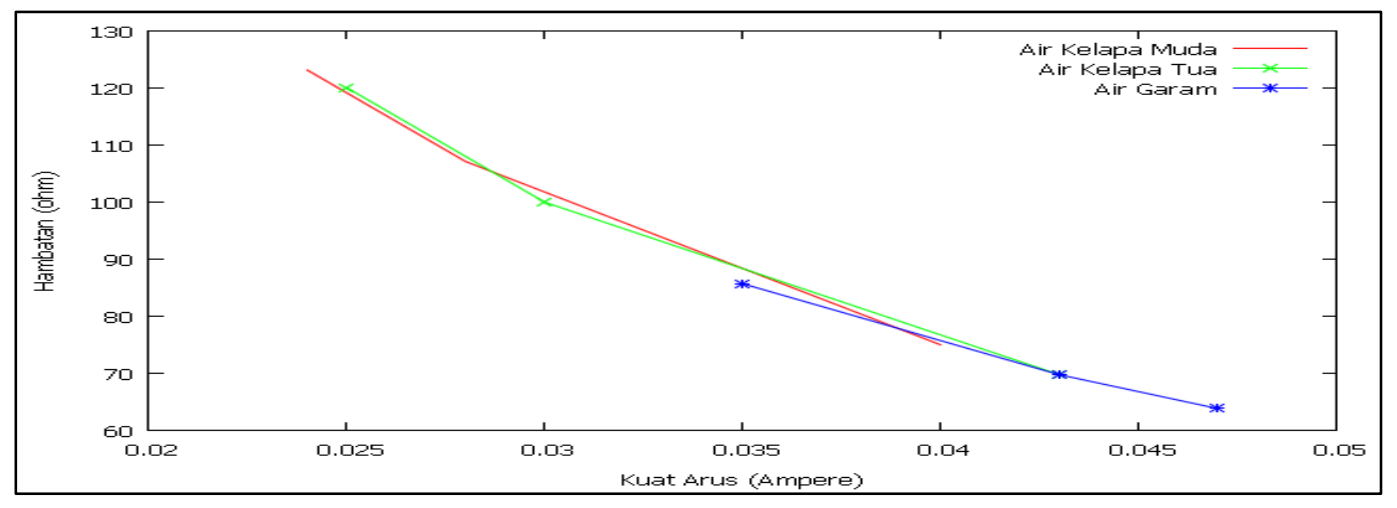

Gambar 1. Grafik Hubungan Kuat Arus Terhadap Hambatan Pada Berbagai Jenis Larutan Elektrolit

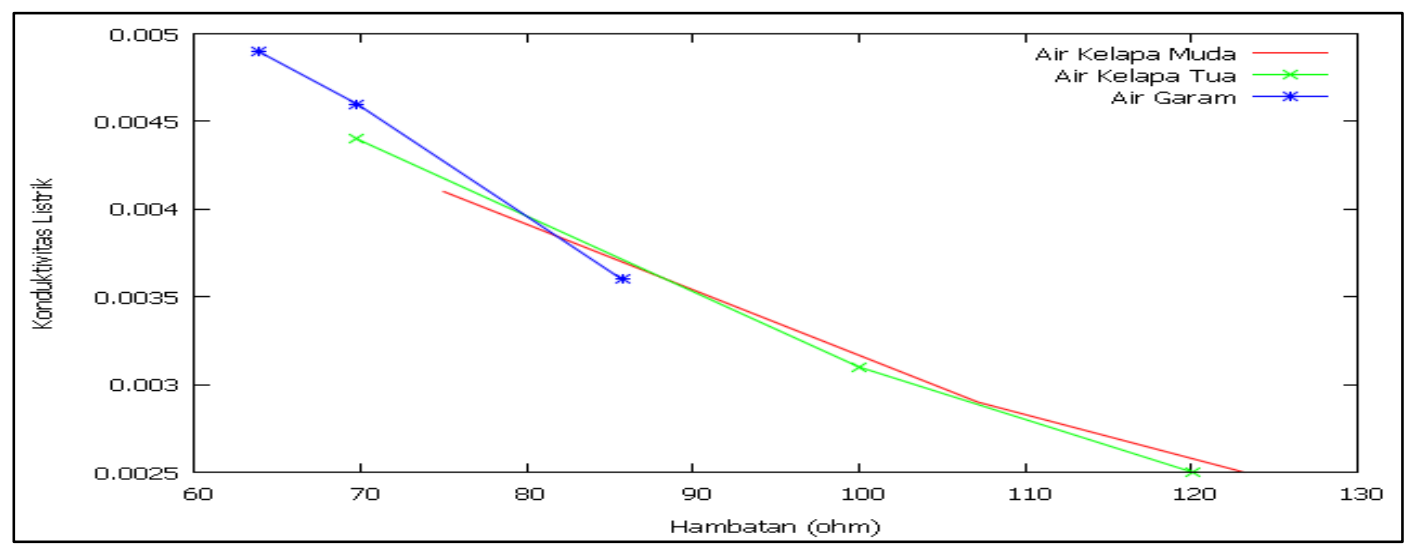

Gambar 2. Grafik Hubungan Hambatan Terhadap Konduktivitas Pada Berbagai Jenis Larutan Elektrolit

Berdasarkan hasil penelitian yang telah dilakukan, perbedaan hambatan yang diperoleh melalui variasi perbandingan volume larutan elektrolit, yaitu semakin besar volume larutan elektrolit maka semakin besar arus yang diperoleh dan semakin kecil hambatan yang terdapat pada larutan elektrolit tersebut sehingga semakin besar kemampuan konduktivitas 
Rumiati., Handayani.,\& Mahardika. - Perbandingan Konsentrasi Larutan ...

listrik pada larutan tersebut. Fadilah menyatakan bahwa "ketika Sehingga, pada data yang dapat air dengan kandungan garam dilihat dari data tabel diperoleh bahwa dialirkan diantara sepasang elektroda rerata larutan yang memiliki yang bermuatan maka elektroda akan kemampuan elektrolit terbesar adalah larutan air garam dibandingkan dengan air kelapa.

Hasil ini sejalan dengan penelitian dengan judul "Pemanfaatan Air Larutan Garam Sebagai kabel Penghantar Listrik Pengganti Tembaga" yang menyimpulkan bahwa penggunaan air larutan air larutan garam sebagai penghantar listrik, jika semakin bertambah massa garam maka daya hantar listrik yang dihasilkan juga semakin besar (Rezki et al., 2019). Kemudian penelitian oleh Zaenab yang dalam penelitiannya menyimpulkan bahwa air garam dapat dijadikan salah satu sumber energi alternative sebagai media yang digunakan untuk menghasilkan sumber energi elektrik ( Haq et al., 2018). Sementara Prastuti berpendapat bahwa "kandungan air laut dan pasir laut berpotensial untuk dimanfaatkan sebagai sumber energi listrik, meskipun pasir laut berperan sebagai hambatan" (Prastuti, 2017). Kemudian berdasarkan penelitian $\mathrm{N}$ mengadsorp ion-ion pada daerah antar muka larutan dan elektrodanya" (Fadilah, 2015). Hal ini senada dengan penelitian Bengi yang menyatakan bahwa yaitu "larutan elektrolit kuat adalah larutan yang dapat menghantarkan listrik dengan baik terdapat pada larutan $\mathrm{NaCl}$ dan larutan HCL" (Bengi et al., 2018). Adapun penelitian tentang air kelapa yang dilakukan Hikmawandari menyimpulkan bahwa "metode spektrofotometri menghasilkan konsentrasi $\mathrm{K}$ dalam sampel air kelapa hijau" (Hikmawandari, 2019). Terintegrasi dengan hal ini, Buwana dalam penelitiannya berpendapat bahwa " Air kelapa muda mengandung $95,5 \%$ air, protein, lemak, vitamin $\mathrm{C}$ dan vitamin $\mathrm{B}$ kompleks. Air kelapa muda juga mengandung sejumlah mineral yaitu nitrogen, fosfor, kalium, natrium, magnesium, klorin, sulfur dan besi. Air kelapa muda mengandung semua elektrolit alami yang dibutuhkan tubuh seperti sodium, kalium atau 
Rumiati., Handayani.,\& Mahardika. - Perbandingan Konsentrasi Larutan ...

potasium, natrium, klorida, kalsium dan magnesium" (Buwana et al., 2016). Sejalan dengan penelitianpenelitian sebelumnya, penelitian yang kami lakukan didapatkan perbandingan dari konduktivitas larutan garam dan air kelapa yang mana hasilnya menunjukkan bahwa larutan garam lebih besar nilai konduktivitasnya dibandingan nilai konduktivitas air kelapa tua dan air kelapa muda.

\section{KESIMPULAN DAN SARAN}

Kesimpulan berdasarkan hasil pengujian konduktivitas listrik larutan garam, air kelapa muda serta air kelapa tua diperoleh hasil bahwa semakin besar volume larutan elektrolit maka semakin besar arus yang diperoleh, sebaliknya semakin kecil hambatan yang terdapat pada larutan elektrolit tersebut semakin besar kemampuan konduktivitas listrik pada larutan tersebut. Jika diurutkan berbagai jenis larutan elektrolit ini berdasarkan kuat arus yang paling tinggi yaitu pertama larutan garam, selanjutnya air kelapa tua dan terakhir air kelapa muda. Urutan ini juga berlaku terhadap konduktivitas listrik dari jenis-jenis larutan elektrolit tersebut.

Saran agar data penelitian lebih variatif maka pengujian juga dapat dilakukan lagi dengan berbagai jenis larutan elektrolit lainnya. Inovatif yang dapat dengan pengembangan alat pengukuran konduktivitas listrik dengan ardiuno.

\section{Ucapan Terima Kasih}

Kami Ucapkan terima kasih kepada seluruh pihak yang terkait dalam penelitian yang kami lakukan diantaranya kepada Lembaga Penelitian dan Pengembangan UHAMKA serta Pogram studi Pendidikan Fisika FKIP UHAMKA.

\section{DAFTAR PUSTAKA}

Rezki, M. A. S., Maliansyah, H., Ariyanto, D. Y., \& Faishal, M. (2019). Pemanfaatan Air Larutan Garam Sebagai Kabel Penghantar Listrik Pengganti Tembaga. Buletin Ilmiah Sarjana Teknik Elektro, 1(2), 6472.

https://doi.org/10.12928/biste.v1 i2.884

Bengi, F. M., Wahyuni, A. S., Syamsuryani, W., \& Mustika, D. (2018). Perbandingan Arus dan Tegangan Larutan Elektrolit berbagai Jenis Garam. GRAVITASI: Jurnal Pendidikan Fisika dan Sains, 1(1), 32-36. 
Rumiati., Handayani.,\& Mahardika. - Perbandingan Konsentrasi Larutan ...

Buwana, P. A., Widjasena, B., \& Suroto, S. (2016). Pengaruh pemberian air kelapa muda (cocos nucifera) terhadap kelelahan kerja pada nelayan di tambak mulyo semarang. Jurnal Kesehatan Masyarakat (Undip), 4(1), 350-358.

Fadilah, N., \& Endarko, E. (2015). Analisa Pengukuran Nilai Konduktivitas Larutan $\mathrm{NaCl}$ Selama Proses Adsorpsi dan Desorpsi pada Sistem Capasitive Deionization (CDI). Jurnal Teori dan Aplikasi Fisika, 3(1).

Hikmawandari, H., Ningsih, P., \& Ratman, R. (2019). Penentuan kadar kalium (k) pada air kelapa hijau (cocos viridis) di Daerah dolo dan labuan menggunakan spektrofotometri.

Jurnal Akademika Kimia, 8(1), 34-37.

Kholida, H., \& Pujayanto, P. (2015). Hubungan Kuat Arus Listrik dengan Keasaman Buah Jeruk dan Mangga. In PROSIDING: Seminar Nasional Fisika dan Pendidikan Fisika (Vol. 6, No.
$1)$.

Putri, L. M. A., Prihandono, T., \& Supriadi, B. (2017). Pengaruh Konsentrasi Larutan Terhadap Laju Kenaikan Suhu Larutan. Jurnal Pembelajaran Fisika, 6(2), 151-157.

Prastuti, O. P. (2017). Pengaruh Komposisi Air Laut dan Pasir Laut Sebagai Sumber Energi Listrik. Jurnal Teknik Kimia Dan Lingkungan, 1(1), 35-41.

Sukisna, S., \& Toifur, M. (2018). Penentuan Konduktivitas Air Baku Proses Desalinasi Di Baron Teknopark Dengan Metode Regresi Linier. In Prosiding SNPS (Seminar Nasional Pendidikan Sains) (pp. 184-190).

Haq, S. Z. N., Kurniawan, E., \& Ramdhani, M. (2018). Analisis Pembangkit Elektrik Menggunakan Media Air Garam Sebagai Larutan Elektrolit. eProceedings of Engineering, $5(3)$. 